\title{
ABOGADA E INTERCESORA. MUERTE Y DEVOCIÓN MARIANA EN EL BUENOS AIRES TARDOCOLONIAL (1750-1810)
}

\author{
POR \\ FACUNDO ROCA ${ }^{1}$ \\ Universidad Nacional de la Plata
}

\begin{abstract}
RESUMEN
El objetivo de este trabajo consiste en explorar las múltiples y variadas vinculaciones entre dos grandes tópicos de la religiosidad barroca: la preparación para la muerte y la devoción a la Virgen María. La invocación mariana en el momento de la muerte ha sido extensamente documentada, aunque desde un enfoque marcadamente cuantitativo. En este trabajo procuramos analizar el papel desempeñado por la Virgen María en el momento de la muerte, resituando esta particular devoción dentro del panorama religioso del Buenos Aires tardocolonial.
\end{abstract}

PALABRAS CLAVE: muerte; Virgen María; Buenos Aires; piedad barroca.

\section{ADVOCATE AND INTERCESSOR. DEATH AND MARIAN DEVOTION IN LATE COLONIAL BUENOS AIRES (1750-1810)}

\begin{abstract}
The aim of this paper is to explore the multiple and varied links between two major topics of baroque piety: preparation for death and devotion to the Virgin Mary. The Marian invocation at the time of death has been extensively documented, although from a markedly quantitative approach. In this paper we analyze the role played by the Virgin Mary at the time of death, within the religious context of late colonial Buenos Aires.
\end{abstract}

KEY WORDS: death; Virgin Mary; Buenos Aires; baroque piety.

CÓMO CITAR ESTE ARTículo / CITATION: Roca, Facundo. 2020. «Abogada e intercesora. Muerte y devoción mariana en el Buenos Aires tardocolonial (1750-1810)». Hispania Sacra LXXII, 146: 501-513. https://doi.org/10.3989/hs.2020.037

$\begin{array}{ll}\text { Recibido/Received } & \text { 26-02-2019 } \\ \text { Aceptado/Accepted } & \text { 02-10-2019 }\end{array}$

\section{INTRODUCCIÓN: «AHORA Y EN LA HORA DE NUESTRA MUERTE»}

La Virgen María ocupaba un papel fundamental dentro del modelo barroco de piedad que se fue gestando, tanto en Europa como en América, a partir de la Contrarreforma. Como afirma Pantoja Barco $(2008,28)$, «la religiosidad y cultura colonial, nacidas bajo el signo de la reforma católica, pondrá un especial énfasis en las devociones más atacadas por los reformadores: el culto al Santísimo Sacramento, la devoción a la Virgen María, a los santos y los sufragios por las almas del purgatorio». Aunque los debates mariológicos no se encontraban en el centro de las diferencias entre

1 facundo.roca@yahoo.com.ar / ORCID iD: https://orcid.org/0000-0002-8012-6441 católicos y protestantes, el culto a la Virgen, como señala Marina Warner $(2013,302)$, «fomentaba precisamente aquellos excesos de idolatría externa [...] que horrorizaban a los hombres que pugnaban por la Reforma». Esta exaltación del culto mariano era particularmente profusa en el mundo hispanoamericano. Patricia Fogelman $(2003,58)$ señala que «el fervor mariano del siglo XVII, reactivado en parte, como reacción frente a la Reforma Protestante, se expandió en América vigorosamente». Según Pantoja Barco $(2008,38)$

\footnotetext{
lo que distingue entonces al barroco de América es «el desarrollo de los temas marianos, tan combatidos por los reformistas", que encontraron a su vez mayor sustento entre los pueblos americanos, dado su carácter profundamente religioso, y la diversidad del lenguaje decorativo.
} 
Al igual que el culto mariano, la meditación y preparación para la muerte constituía otro de los grandes tópicos de la piedad barroca. ${ }^{2}$ El recuerdo de la muerte debía incitar al fiel al rechazo de las veleidades y vanidades de la vida profana, así como al abandono del «siglo» o del «mundo». La certeza de la finitud y fugacidad de la vida aguijoneaba la conciencia del hombre barroco, alimentando los temores y ansiedades en torno al destino del alma en el más allá. Dentro de esta "pastoral del miedo», la Virgen María ocupaba un papel fundamental. ${ }^{3}$ Ella desempeñaba el rol de abogada o intercesora, interviniendo para aliviar las penas del pecador arrepentido, salvarlo del «error» y prevenir la condenación eterna. El avemaría, una de las principales oraciones católicas, incluida ya en su formato actual en el Catecismo de Trento, consagraba esta función salvífica del culto mariano: «ruega por nosotros, pecadores, ahora y en la hora de nuestra muerte».

La invocación a la Virgen María en el momento de la muerte ha sido extensamente documentada a partir del estudio serial de las cláusulas testamentarias. Las investigaciones sobre la historia de la muerte desarrolladas en Francia y España a partir de la década de 1970, especialmente en la línea inaugurada por Michel Vovelle (1973), han constatado la universalidad de estas cláusulas entre los testadores del Antiguo Régimen. La intercesión mariana también se encontraba ampliamente extendida en el Río de la Plata, como muestran los trabajos de María Isabel Seoane (2006, 34-35) sobre Buenos Aires y de Ana María Martínez de Sánchez (1996, 26-28) sobre Córdoba del Tucumán. ${ }^{4}$ Sin embargo, estudios más recientes coinciden en advertir los riesgos y limitaciones que implica un análisis meramente cuantitativo de las fuentes notariales. Diferentes investigadores han señalado el carácter puramente formal y estandarizado de estas cláusulas, cuestionando su presunta relevancia como indicador de la piedad y fervor religioso de los testadores. Como señala Anastasio Alemán Illán $(2001,171)$, «el otorgante no controla la redacción del acta, siendo ésta fruto, en buena medida, de la aplicación de los repertorios de fórmulas existentes o del aprendizaje empírico [...] del futuro escribano».

El objetivo de este trabajo consiste en demostrar que la primacía de la invocación mariana, lejos de constituir una declaración meramente formal, reflejaba el fortalecimiento

\footnotetext{
2 En su análisis sobre los testamentos provenzales, Michel Vovelle (1973) ha señalado un quiebre muy marcado del modelo barroco a partir de las décadas de 1750 y 1760 . Sin embargo, en el Río de la Plata se puede hablar de una perduración de la religiosidad barroca, a pesar de la creciente influencia ilustrada, por lo menos hasta fines de la centuria. Sobre la influencia de la piedad ilustrada en la región rioplatense, cfr. Peire (2000) y Di Stefano y Zanatta $(2000,159 s s$.$) . Con respecto a la his-$ toria de la muerte existe una extensa y variada bibliografía, tanto para España como para América. Una interesante recapitulación de la producción historiográfica española puede verse en Gómez Navarro (2010).

3 Según Georges Minois (2005), los períodos de «renovación moral», como la Contrarreforma, imponen un endurecimiento de las penas y sanciones del más allá. De acuerdo con el historiador francés, «el siglo XVII es elitista y pesimista: son muchos los llamados, pero pocos los elegidos, repiten al unísono teólogos, predicadores, místicos y autores espirituales [...] La pastoral del miedo exige un infierno repleto» (Minois 2005, 338).

4 Esta última autora destaca que «el culto a María, Madre de Dios, se hallaba muy difundido en Córdoba en el siglo que nos ocupa, como lo muestra la profusión de imágenes y de lienzos que la representaban» (Martínez de Sánchez 1996, 27).
}

de una devoción muy popular y extendida en el Río de la Plata tardocolonial. Las exhortaciones a la Virgen María, como mediadora y abogada de los difuntos, dan cuenta del papel crucial que ésta desempeñaba dentro del modelo barroco de buena muerte. Las fuentes analizadas demuestran que hacia fines del período colonial la devoción a la Virgen como abogada y protectora, en lugar de disminuir, se acrecentó y reforzó con la proliferación de diversas cofradías y hermandades. A diferencia de lo que ocurría en la península, en la segunda mitad del siglo XVIII Buenos Aires experimentó un proceso de revitalización de la actividad cofradiera, estrechamente ligado a la expansión y consolidación del culto mariano. ${ }^{5}$ Asimismo, procuramos demostrar que este fervor devocional no solo concernía a una preocupación espiritual o soteriológica, sino que permitía canalizar y sublimar muchas de las inquietudes y ansiedades que asaltaban al moribundo en su lecho de muerte, incluso aquellas de carácter puramente terrenal.

En este trabajo analizamos algunas de las formas mediante las cuales se enlazaban estos dos grandes tópicos de la religiosidad barroca: la preparación para la muerte y la devoción o culto a la Virgen María. Nuestro análisis se centra en las décadas finales del período colonial (1750-1810) y abarca un espacio que comprende tanto a la ciudad de Buenos Aires como a su hinterland o campaña circundante. No pretendemos en este texto agotar las múltiples articulaciones entre muerte y culto mariano, sino más bien señalar algunos de los mecanismos mediante los cuales se expresaba y reforzaba esta relación dentro del panorama religioso tardocolonial. Para esto analizamos tanto textos devocionales como testamentarias, obras artísticas y documentos de cofradías.

\section{LA VIRGEN Y LA MUERTE: DOLORES Y ASUNCIÓN}

La asociación de la Virgen con la muerte, ya sea la propia o la de Cristo, es sumamente estrecha. En el ciclo mariano, la muerte del Hijo tiene su representación en la Virgen Dolorosa, así como en una variante de ésta, particularmente popular en el mundo hispánico, Nuestra Señora de la Soledad. Otro momento crucial en la vida de la Virgen es el fallecimiento de su "amantísimo esposo», San José. A este último se le atribuía precisamente el patronazgo de la «buena muerte», por haber fallecido en brazos de María y de Jesús. Los testamentos coloniales invocaban el nombre del esposo de la Virgen insistentemente, ${ }^{6}$ la cofradía de ánimas asentada en el hos-

5 Existe una amplia y variada bibliografía sobre cofradías en el mundo hispánico. Un balance de la producción historiográfica reciente puede verse en Arias de Saavedra Alías y López-Guadalupe Muñoz (2017). La mayoría de estos estudios coinciden en que la última mitad del siglo XVIII fue un período de profunda crisis y transformación de la vida cofradiera. José Sánchez Herrero $(2003,172)$, por ejemplo, afirma que ésta fue una etapa poco propicia «para la fundación de cofradías, al menos del tipo de las de Semana Santa». Sin embargo, como señala López Carvajal (2013 y 2015), el reformismo borbónico no tuvo las mismas consecuencias ni se aplicó con igual intensidad en todas las regiones del imperio. Sobre las hermandades y cofradías en el Buenos Aires colonial, cfr. Di Stefano (2002), González Fasani (2006), González (2005) y Jijena (2006). Sobre las cofradías marianas en particular, puede verse Fogelman (2000).

6 Según María Isabel Seoane (2006, 35-36), la presencia de José como intercesor es, no obstante, posterior a la de María, difundiéndose recién a partir de inicios del siglo XVIII. 
pital de los betlemitas se situaba bajo su protección, y Fray José Antonio de San Alberto, arzobispo de Charcas, le dedicó su Despertador y ejercicios espirituales para vivir y morir bien, impreso en Buenos Aires en 1789. La propia muerte de María (también llamada Dormición o Tránsito) constituía un motivo muy popular dentro de la imaginería religiosa local y era celebrada todos los años en la festividad de la Asunción. Estos y otros pasajes más de la vida de la Virgen reforzaban su asociación con el momento de la muerte y su condición de intercesora en aquel «último lance».

FIGURA 1

Nuestra Señora de los Dolores, anónimo (Cádiz), madera policromada y ojos de vidrio, 1756. Buenos Aires, Catedral Metropolitana

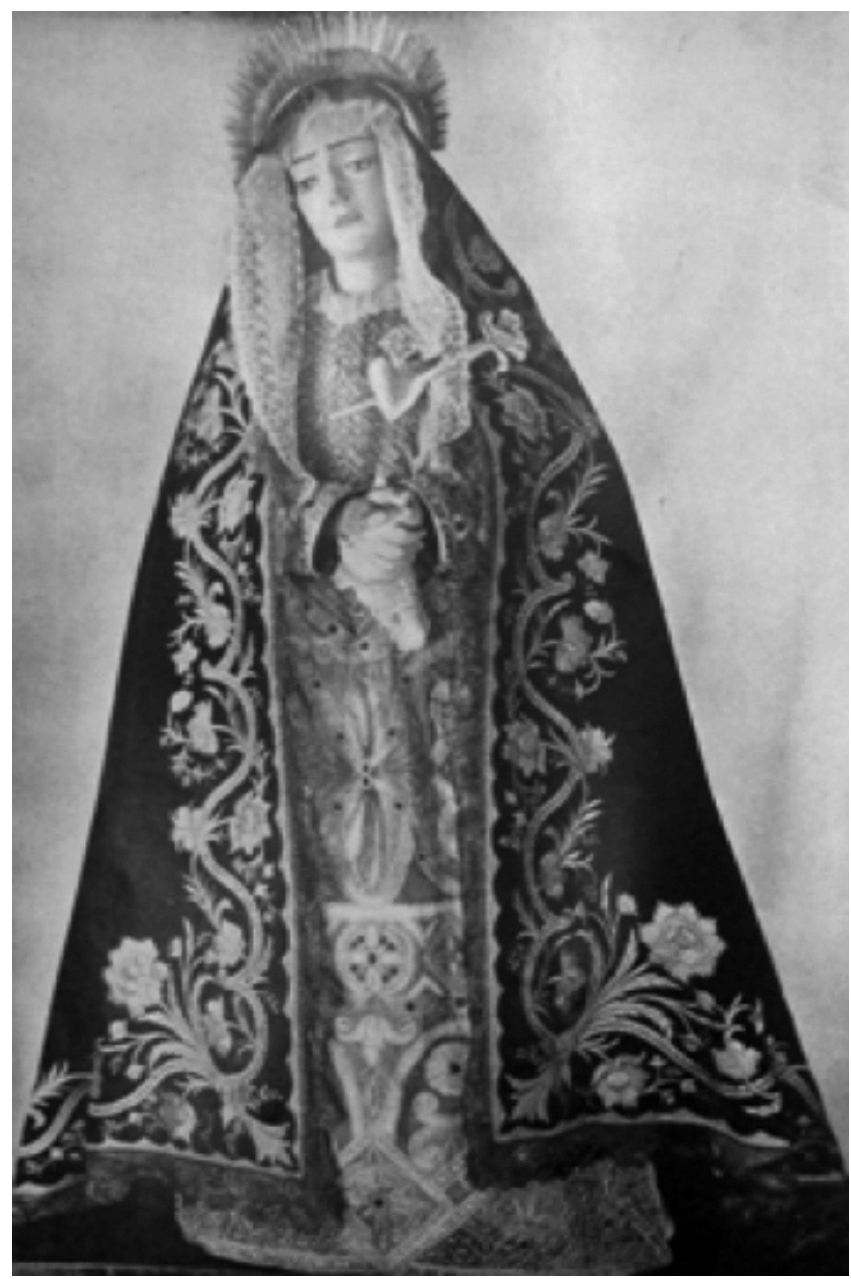

Fuente: Reproducido en Ribera y Schenone (1948, fig. 2).

La Virgen de los Dolores, cuyas primeras representaciones se remontan al siglo XIV, desempeñó un papel fundamental dentro del escenario devocional tardocolonial. Junto con la Inmaculada Concepción, la Dolorosa era una de las advocaciones marianas más populares dentro del mundo hispánico. ${ }^{7}$ A ella estaba consagrada una de las cofradías

7 Estela Barbero $(1994,328)$ ha constatado, en base al análisis de inventarios, que la Virgen de los Dolores era la segunda advocación mariana más popular en el Buenos Aires virreinal, solo superada por la Inmaculada Concepción. más prestigiosas de Buenos Aires, la de Nuestra Señora de los Dolores y Ánimas, instituida en 1750 en la Iglesia Catedral. La imagen venerada por los cofrades porteños (Fig. 1) expresaba, como señala Ricardo González (2005, 478), una nueva concepción del culto mariano, que se alejaba completamente de la vieja estética medieval:

La escultura gaditana [de la Dolorosa] muestra igualmente la sutil transformación del tipo de imágenes devocionales de María, que abandonando todo resabio de medievalismo, presenta formas más naturalistas. Sin dejar de lado la frontalidad y la pérdida de la anatomía bajo el envoltorio de los ropajes, introduce una descripción más verista a través de pequeños detalles como la leve inclinación de la cabeza y la gestualidad que impregna el rostro y las manos. Se incorpora así un enfoque más realista de la representación que intenta mostrar de un modo vívido los sentimientos del personaje en su situación concreta, es decir humanizar la imagen de la Virgen presentándola, no como un ícono lejano, sino con rasgos personales.

En 1793, la cofradía obtuvo la aprobación real para su elevación a la condición de Orden Tercera de los Siervos de María (Servitas). ${ }^{8}$ Esta hermandad, fundada en el siglo XIII, había recibido un fuerte impulso durante la Contrarreforma, especialmente bajo el pontificado del Papa Pablo V. Los cofrades porteños sostenían regirse por las lecciones contenidas en el Congregante y siervo perfecto de la Santísima Virgen de los Dolores, un manual devocional escrito por el religioso español Fray Lorenzo Reymundínez. En su obra, Reymundínez $(1785,215)$ dejaba en claro el estrecho nexo que unía a María con la agonía de su hijo y con la «buena muerte»:

Afligida y, desconsolada Virgen María, Madre de pecadores, yo os adoro, y reverencio por la agonía que padecisteis viendo con vuestros purísimos ojos morir a vuestro Hijo, tan vilipendiado de todo el mundo; y os suplico humildemente me concedáis vuestra asistencia en las agonías de la muerte, y me consigáis de su Divina Majestad un verdadero arrepentimiento de todas mis culpas, y pecados, para tener una buena, y reconocida muerte. Amén.

Según Fernando Martínez Gil (2000, 245), «la divinidad constituía a veces un concepto demasiado abstracto y lejano». La Virgen, al igual que los santos, operaba como mediadora o intercesora ante ese Dios inalcanzable. La madre que había visto la agonía de su hijo en la cruz no podía ser indiferente al sufrimiento y la muerte del fiel cristiano. La Virgen sufriente conocía de cerca el dolor de la muerte y se apiadaba del alma del moribundo arrepentido. En su semblante, lleno de ternura y aflicción (muy lejano del hieratismo medieval), se dibujaba la imagen misma de la misericordia y la piedad. Como señala Marina Warner $(2013,227)$, «la Mater Dolorosa consuela a los desconsolados ya que ella comparte su dolor».

Esta confianza en la intercesión mariana explica, en gran medida, la popularidad y difusión de la que gozaba el culto a la Madre Dolorosa. A ella estaban dedicadas innumerables representaciones, tanto en pinturas como en imágenes

8 Archivo General de la Nación, Buenos Aires (en adelante AGN), 9-31-6-4, exp. 909. 
de bulto. Además de la capilla que la cofradía mentada poseía en la catedral, también se hallaban consagrados a la Dolorosa un retablo en el convento de los recoletos y uno de los altares laterales de la Capilla de San Roque, perteneciente a los terciarios franciscanos. Asimismo, podía encontrársela en retablos dedicados a otras advocaciones, como el de Santa María del Socorro, en la iglesia de la Merced, o en los Calvarios, como el que aún se conserva en la Santa Casa de Ejercicios. Por otro lado, las testamentarias ilustran el predominio de esta advocación mariana dentro de los objetos privados de culto. ${ }^{9}$ Algunos fieles llegaban a poseer incluso más de una imagen, como Eugenio Lerdo de Tejada, que tenía entre sus muchos cuadros piadosos dos lienzos de la Dolorosa, uno con vidrio y otro sin él, ${ }^{10}$ o Isidoro Rodríguez de la Peña, que poseía «una laminita de Nuestra Señora de los Dolores y dos laminitas de Nuestra Señora de las Angustias». ${ }^{11}$

La Mater Dolorosa, cuyas primeras representaciones se remontaban al período bajo-medieval, había adquirido un papel privilegiado dentro de la piedad barroca. En ella se expresaba, como señala Rosita Pantoja $\operatorname{Barco}(2008,81-82)$, una concepción específica de la muerte:

La presencia de la Virgen María en la escena de la muerte de Cristo vendrá a reafirmar el cambio en la concepción de la muerte puesto que el acto de morir deja de ser un espacio silencioso para convertirse en un espacio de expresión pública. Asimismo, la aparición de la Madre aumenta el carácter bienaventurado y doloroso de la muerte, pues el abandono de la vida se realiza en presencia de personajes santos y en un aura de consuelo, donde el dolor de la madre es el anuncio de una nueva espera. La muerte ya no es un acto horroroso y tampoco potestad del maligno, el temor y la oscuridad total y sin remedio se transforman en una promesa y es posible decir que en un acto de dulzura.

La madre que sostiene al Hijo difunto en sus brazos, como en la Piedad, o la que lo llora a un costado de la escena, como en la Lamentación sobre Cristo muerto (Fig. 2), ofrecía a los fieles una posibilidad de identificación y un código de conducta a seguir. Estas representaciones revestían un sentido pedagógico y ejemplarizante: el sufrimiento debía ser morigerado por la circunspección, el recogimiento, la resignación y el abandono. Como señala Pantoja Barco (2008, 82-83), "la virgen espera resignadamente la muerte de su hijo y su propia muerte para unirse a él, confía en la unión venidera, aguarda el advenimiento de la resurrección, prepara el camino y conforta a quien ha de morir». Esta era precisamente la actitud que debía tomar el fiel agonizante. En palabras del obispo San Alberto $(1789,197)$, «la primera [disposición], la mejor, la más conveniente, y aún la más necesaria, es aceptar la muerte con una perfecta resignación».

9 Sobre piedad e imaginería privada en el Río de la Plata, cfr. Barbero (1994) y Rípodas Ardanaz (1996). Sobre la iconografía mariana en la Hispanoamérica colonial, cfr. Schenone (2008).

10 AGN, Sucesiones 6727, Testamentaria de Eugenio Lerdo de Tejada.

11 Cfr. González (2005, 259). Nuestra Señora de las Angustias es una variante de la Virgen Dolorosa, venerada en Ayamonte, provincia de Huelva.

\section{FIGURA 2}

Lamentación sobre el cuerpo de Cristo, anónimo (Italia), óleo sobre tela, último tercio del siglo XVII. Buenos Aires, iglesia de San Miguel Arcángel

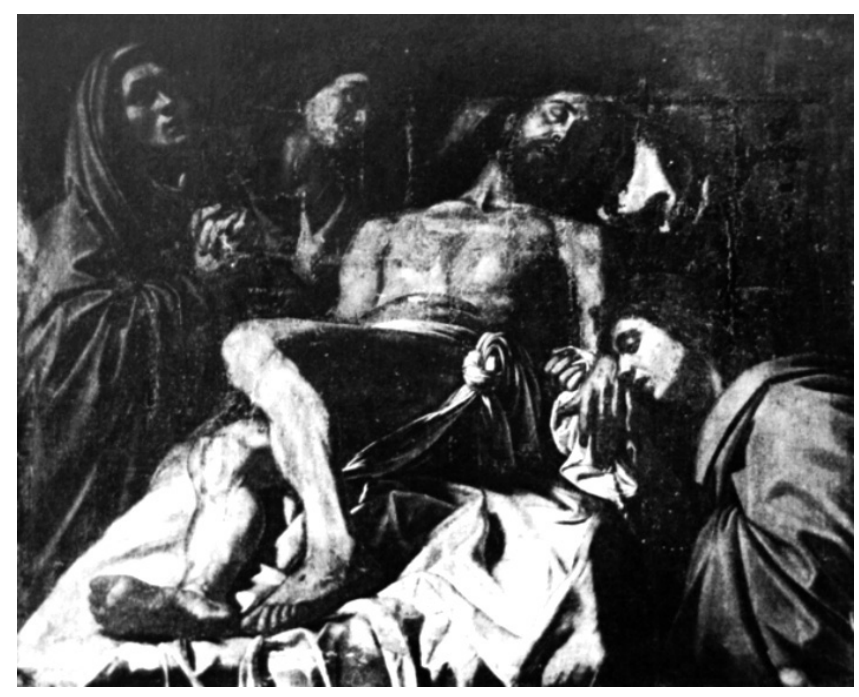

Fuente: Reproducido en Academia Nacional de Bellas Artes (ANBA) (1998, 276).

No era difícil para el hombre colonial empatizar con esta Mater Dolorosa que venía a "dulcificar» la escena de la muerte. Ella consolaba y aquietaba las angustias del moribundo, disipando los temores y ansiedades que asaltaban al agonizante. No en vano los cofrades de la Hermandad de Dolores y Ánimas de Buenos Aires recordaban que la Virgen le había dicho a Jesús: "Yo te enviaré libre de aquellas congojas para el cielo, sin entrar en el Purgatorio». ${ }^{12}$ La misma o similar fortuna esperaban gozar los hermanos, por intercesión de María Santísima.

Menos extendida, pero igualmente ilustrativa de la conexidad entre culto mariano y "buena muerte», era la devoción por la Asunción de María. ${ }^{13} \mathrm{Al}$ igual que la Inmaculada Concepción, la doctrina según la cual la Virgen había sido preservada de la muerte, al ascender a los cielos en cuerpo y alma, no era aún reconocida como dogma, aunque su culto se encontraba ampliamente difundido por toda la Hispanoamérica colonial. Imágenes y tallas, como la Virgen del Tránsito de la iglesia de San Ignacio (Fig. 3), ilustraban, en sus rostros serenos o extáticos, el carácter virtuoso y apacible de las «preciosas muertes». Nada había de traumático ni de perturbador en esas postrimerías.

El Catón Christiano, un popular catecismo reimpreso en Buenos Aires en 1795, asociaba explícitamente la Asunción o «dichoso Tránsito» de la Virgen con su carácter de mediadora e intercesora en el momento de la muerte: «El quarto [de los misterios gloriosos es], el dichoso Tránsito de la Virgen, pedirla, que siempre sea su abogada, en especial en la hora de la muerte, que con su presencia, y ayuda se le haga fácil, y suave» $(1795,88)$. La representación de esta muerte santa, convertida en un sueño o un tránsito «fácil y suave», buscaba conjurar el temor que suscitaba aquella

12 Citado en González (2005, 255).

13 Sobre la Asunción de María, cfr. Warner (2012, 83-105) y Fogelman $(2010,167-169$ y 2014, 212ss.). 
FIGURA 3

Virgen del Tránsito, anónimo (Quito), siglo XVIII, mascarilla de plomo y ojos de cascarón. Buenos Aires, iglesia de San Ignacio (desaparecida en 1955)

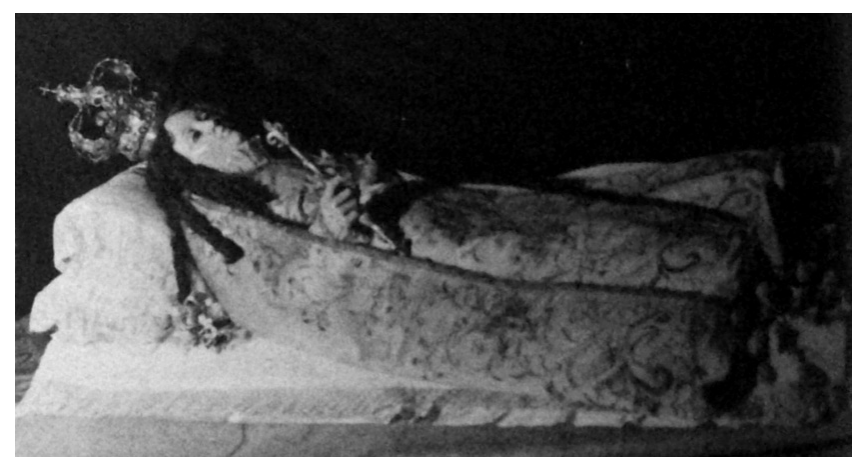

Fuente: Reproducida en ANBA $(2010,118)$.

separación traumática entre carne y espíritu, de la que había sido librada María por gracia de su Hijo. Aunque la asunción al Cielo en cuerpo y alma era privativa de la Madre de Dios, ${ }^{14}$ esta muerte apacible ofrecía un mensaje reconfortante y esperanzador para el fiel católico, al preanunciar la gloria futura que correspondía a toda alma piadosa.

\section{EL TEMOR Y LA MISERICORDIA}

Los testamentos del siglo XVIII recogen de forma literal el temor ante la muerte, tan frecuente y llanamente expresado en la piedad barroca. "Temiéndome de la muerte, que es cosa natural a todo viviente», es una de las frases más usuales con que dan comienzo las últimas voluntades. Más allá de constituir fórmulas fijas o estandarizadas, estas expresiones ilustran un sentimiento generalizado, que predomina en las sociedades de Antiguo Régimen. Según Philippe Ariès (1984, 115), las imágenes de la muerte y la descomposición, tan frecuentes en el arte renacentista y barroco, «son el signo de un amor apasionado por el mundo terrestre, y de una conciencia dolorosa del fracaso al que está condenada cada vida de hombre». La forma elíptica y dramática de referirse a este momento también da cuenta de los temores y ansiedades del testador. Los fieles aluden a la hora de la muerte como "aquel último aprieto», "aquel formidable momento», o ese «lance tan terrible» y "tremendo».

El temor a la muerte era demasiado poderoso, como para no intentar conjurarla. Cuando la medicina ya no daba respuestas, la encomendación a la Virgen y a los santos, las ofrendas, visitas y promesas, se constituían en uno de los últimos recursos del enfermo. En Buenos Aires, la cofradía de San Benito de Palermo, famoso taumaturgo del siglo $\mathrm{XVI}$, contaba con un "santo enfermero» y dos reliquias (una partícula de un dedo y otra de «carne») que se llevaban a las casas de los cofrades enfermos. ${ }^{15}$ Algunas advocaciones marianas, como Nuestra Señora del Carmen, también eran famosas por su poder terapéutico y sus milagrosas curaciones. Como señala María Elena Barral $(2007,182)$, esta última

14 El popular catecismo del padre Astete $(1787,215)$ definía precisamente a la muerte como «la separación del Alma racional, del cuerpo humano".

15 Cfr. González (2005, 311-312). «tenía el atractivo del escapulario, una especie de amuleto protector que bien, o prevenía contra la muerte, o aseguraba que nadie que muriese con él podría sufrir penas eternas». Según José Pedro Barrán $(1998,49)$, en la vecina ciudad de Montevideo, un $16 \%$ de los testadores eligieron como mortaja el hábito de Nuestra Señora del Carmen. ${ }^{16}$ Algunos fieles porteños, como el pulpero Antonio González Varela ${ }^{17}$ o el sargento José Troly, ${ }^{18}$ disponían misas o legaban dinero para costear su fiesta. En Buenos Aires, esta devoción había ameritado la fundación de una cofradía específica, asentada en la iglesia de La Concepción y formalmente instituida en $1786 .{ }^{19}$

El ruego a María podía ser tanto o más efectivo que los aires benéficos del campo o la atención de un reconocido médico o curandero. En 1769, por ejemplo, José Pereyra de Luzena, vecino y comerciante de Buenos Aires, había dejado asentado lo siguiente en su libro de cuentas: «el dia 30 de Jullio [...] salio de esta Ciudad para la Costa de San Isidro mi Hija doña Maria Martina, a ver si con los aires del Campo podía mejorar de la penosa enfermedad, que padecia con la asistencia de un mata sanos que alli se hallaba». ${ }^{20}$ Entre los gastos de su hija, Pereyra consigna una partida de 2 pesos «por la compostura de una Coronita de plata de una Imagen de Nuestra Señora que allí le llevaron, pidiendo la salud $» .{ }^{21}$ La actitud de Pereyra de Luzena no era para nada excepcional. Los votos y promesas en peligro de muerte eran una constante en la sociedad colonial. Ya en 1695, Tomasa Machado había declarado «en su testamento el voto que hizo por la salud de su hijo a la virgen de Luján de ofrecerle lo que el niño pesaba en cera». ${ }^{22}$ Hacia 1789, "el comandante del cuerpo de Astilleros Don Manuel de Rivera mandó hacer, como un voto cuando padecía una grave enfermedad», el primer grabado que se conoce de la Virgen de Luján. ${ }^{23}$ Como demuestran estas promesas y exvotos, la fe en las curaciones y remedios de los hombres no era incompatible con la «divina medicina».

Quienes no tenían nada que ofrecer, como el pardo Fernando Santos de Agüero, un barbero viudo sumido en la miseria, empeñaban su propia fuerza de trabajo en aras de una curación milagrosa. En 1786, su hija Pascuala envió una carta al albacea testamentario de su padre, solicitándole 12 pesos para cumplir la promesa que este le había hecho, antes de fallecer, a la Virgen de Luján. Según Pascuala, su padre, "habiéndole asaltado [...] el accidente perlettico, le ofreció de todo Corazòn à nuestra Señora de Lujàn, el que si le consedia la vida, de hir a su santa Capilla, distante desta ciudad dies y seis leguas en mi Compañia, a servirle, el espacio de un año a dicha Soberana Señora». ${ }^{24}$ Los "prolijos

16 En Buenos Aires el hábito del Carmen estaba menos extendido (cfr. Seoane 2006, 59), aunque su uso no constituía una práctica infrecuente.

17 AGN, Protocolos notariales, Registro 1, 1780, f. 212.

18 AGN, Protocolos notariales, Registro 1, 1780, f. 50.

19 Cfr. AGN, 9-31-4-8, exp. 511. En 1800 los cofrades piden autorización para publicar un impreso con las indulgencias del escapulario, basándose en un ejemplar traído de Sevilla. El mismo puede consultarse en AGN, 9-31-7-7, exp. 1200.

20 Archivo Histórico de la Provincia de Buenos Aires, La Plata: Argentina (AHPBA), Real Audiencia, 5-1-4-5, 1789, f. 55.

21 Ídem.

22 Citado en Barral $(1998,23)$.

23 Ídem.

24 AGN, Sucesiones, 3864, Testamentaria de Fernando Santos de Agüero, f. 29. 
achaques» que padecía le habían impedido al barbero cumplir con su promesa. Ya moribundo, este le había pedido a su hija «por muchas oraciones» que hiciese esa «devoción» en su nombre. Aunque Pascuala se excusaba de realizar el viaje por "ser casada" y carecer de medios suficientes, no quería dejar de cumplir la última voluntad de su padre. Luego de consultar el dilema con "personas piadosas y capaces» (presumiblemente un clérigo), había resuelto "conmutar» la promesa en una limosna de 12 pesos, «con lo que me conformè y conformo: por resultar en culto, de tan Divina Señora y alivio del Alma de mi dicho difunto Padre». ${ }^{25}$

Enfermo y en cama, Santos de Agüero había implorado a la Virgen que le «concediera la vida». La esperanza de una curación milagrosa había llevado al barbero, como a tantos otros, a encomendarse a Nuestra Señora de Luján. La promesa expresaba el apego y amor por la vida, tanto como el temor a la muerte. Lejos de aquel ideal de desprecio y rechazo del "mundo" (el contemptus mundi de raigambre medieval), lo que procuraba el barbero con este ruego era prolongar su existencia, diferir el momento de la muerte. Quizá Agüero también se viera atormentado por los remordimientos y temiera el momento del juicio. Acosado por las deudas y padre de cinco "hijos bastardos», probablemente sintiera que tenía mucho de que arrepentirse. Lo interesante de estos casos es que el agravamiento ulterior de la enfermedad no extinguía la promesa. El motivo de este comportamiento lo expresa su propia hija en la carta citada. Si antes el ruego a la Virgen era por la salud del cuerpo, ahora lo era por la «salud del alma».

Las invocaciones, lejos de extinguirse ante la certeza de una muerte inevitable, se redoblaban en estos últimos instantes. El fiel sabía que a la muerte seguía el juicio, instancia decisoria en la cual habría de definirse el destino del alma para toda la eternidad. En palabras del obispo San Alberto $(1789,254)$, «después de este último arranque y salida del alma, ella será citada ante el Tribunal de Dios [...] iPobre alma! Ella será citada sin dilación, acusada sin reserva, juzgada sin aceptación, y sentenciada sin apelación». Pero mientras que el Padre y el Hijo representaban el rigor y la rectitud del juicio (la «ira del Justo Juez»), María era asociada con la misericordia, que podía torcer a último momento el fiel de la balanza en favor del moribundo arrepentido. Como señala Marina Warner $(2013,323)$, «la Virgen le da al Cristo Juez su rostro humano», transformando "al Dios de la justicia en el Dios de la misericordia». María se constituye, en palabras de los cofrades de la Hermandad de Dolores, en "la Mediadora entre Dios y el hombre, entre el Juez y el pecador». ${ }^{26}$ Según Ariès $(1984,92)$

el juicio no sigue siempre la elección de la balanza. Las intercesiones aparecen y juegan un papel que no había previsto el texto de san Mateo, el papel conjugado del abogado (patronus), del suplicante (advocare deum) que apelan a la piedad, es decir, a la gracia del soberano juez.

25 Ibíd. La conmutación de votos y promesas por trabajo y bienes era una práctica frecuente en el Río de La Plata colonial. Como señala María Elena Barral $(1998,23)$, la limosna constituía una «ocasión propicia "para conchabarse para buscar la vida" o para cumplir promesas, o bien para ambas cosas a la vez».

26 AGN, Biblioteca Nacional, 395, exp. 6608, f. 11.
El Catón Christiano recomendaba expresamente la invocación a María en aquel momento y ofrecía además un breve compendio de «Oraciones diversas a la Virgen para alcanzar buena muerte, y decirlas en su artículo». Asimismo, en sus rústicos Elogios a la Virgen Santísima, escritos entre 1807 y 1810 , el comerciante José Serra y Valls, vecino de Buenos Aires y natural de Barcelona, se acogía a esta vieja tradición e invocaba la intercesión mariana en esta «última hora»:

Después de Dios, gran Señora,
a vos adoro y venero,
y de vuestro amparo espero
favor en mi última hora.
Mostraos mi protectora
en aquel lance terrible
que el Enemigo invisible
mis culpas presentará
a Dios que las juzgará
con un juicio irremisible
[...]
Por la bondad del Señor
que tan hermosa os formó,
os ruego y suplico yo
que me amparéis con amor,
porque soy gran pecador
y de Dios temo el poder
pues, pensando en mi vil ser
y en el gran mal que tengo hecho,
se me estremece a mí el pecho
y hallo mucho en que temer.
(Serra y Valls $2000,244-245$ ).

En sus elementales versos, Serra y Valls evocaba la imagen tradicional del Juez riguroso y de la intercesión y misericordia mariana. "De Dios temo el poder», decía el comerciante catalán, ya que él «juzgará [mis culpas] con un juicio irremisible». Por el contrario, era María quien ofrecía su amparo y consuelo en aquella «última hora»: "Pero ayudándome vos/¿¿de qué tendré que temer?,/¿ignoro acaso el poder/que obtenéis delante Dios?» (Serra y Valls 2000, 245)

Como demuestran estos testimonios, el momento de la muerte era también el del remordimiento y el temor. El pecador, contrito y arrepentido, dirigía su mirada a la Madre de Dios. Simón Machado, vecino de Baradero, invocaba en su testamento de 1784 a María Santísima como su «yntersesora, y Abogada; Como se lo suplico, y lo A sido Toda mi Vida». ${ }^{27}$ Los temores de Machado ante la inminencia del juicio afloran detrás de la redacción del testamento: «por quanto tengo Algun escrupulo de mi Consiensia sobre si haber Cumplido bien con las penitencias respectibas a mis Culpas Confesadas [...], es mi voluntad que porque Dios se digne Apiadarse de mi Alma se diga una misa por las benditas Animas del Purgatorio». ${ }^{28}$

El alma atormentada del pecador solo encontraba consuelo en la intercesión mariana, en la misericordia divina y en aquellos instrumentos destinados a propiciarla: sufragios, indulgencias y obras pías. El testamento atestigua las inquietudes y ansiedades del moribundo. Como señala Máximo García Fernández $(2003,224)$ «el hombre, en los últimos instantes de su vida, "sintetiza apresuradamente temores y creencias, pánicos y esperanzas que presiden un tránsito organizado», trata por todos los medios a su

\footnotetext{
27 AGN, Sucesiones, 7151, Testamentaria de Simón Machado, f. 1. 28 Ibíd., f. 2.
} 
alcance [...] de solventar sus problemas "de conciencia" o "penitencias mal cumplidas"».

La Virgen se constituye en la compañera privilegiada de estos "últimos instantes». Así lo confirman los relatos de quienes presencian y describen estas agonías. Por ejemplo, en diciembre de 1787, Francisco Antonio Gallarza le envía, desde Madrid, una carta a Catalina Ruiz de Arellano, comunicándole la «infausta nueba de la muerte de su Esposo, Señor Don Baltasar de Arandia». ${ }^{29}$ Vecino y «del comercio de Buenos Aires», Arandía se encontraba realizando gestiones en esa Corte cuando lo asalta la muerte. En su misiva, Gallarza describe los instantes finales del moribundo: luego de recibir el viático y dictar su testamento, este no se apartó de su confesor y «se dedico todo a Dios; cuio nombre y el de María Santisima no cesó de inbocar hasta los ultimos periodos de su vida». ${ }^{30}$

\section{LA «MADRE DE LAS ALMAS»}

El culto a las ánimas del purgatorio se encontraba en el corazón de la piedad barroca, heredera del Concilio de Trento, al igual que el renovado fervor mariano propiciado por la Iglesia colonial. Tanto una como otra devoción constituían parte de los principales blancos hacia los que se habían dirigido las críticas más acerbas de los protestantes. Como señala Fernando Martínez Gil (2000, 285), con la Contrarreforma, «se potencian las prácticas tradicionales (misas fundaciones, cofradías) y la devoción a las ánimas del Purgatorio». El Buenos Aires colonial no constituía una excepción dentro de este panorama. Todos los días y en todas las iglesias se realizaban sufragios por las benditas ánimas. En 1799, los feligreses de la parroquia del Socorro expresaban este fervor con suma claridad:

Es tan connatural, y propia a todos los Fieles christianos [...], la piadosa devocion a las Benditas Animas del Purgatorio, que puede decirse con razon, que nacen y crecen con ella desde su infancia. [...] Apenas havia quien por amortiguada que tenga en su corazon la virtud de la caridad no haga alguna vez recuerdo de las penas que padecen aquellas, y proceda con tal qual sufragio al alivio y consuelo de sus incesantes padecimientos. ${ }^{31}$

Este fervor se expresó en la rápida proliferación de las cofradías abocadas a esta devoción, sobre todo a partir de mediados del siglo XVIII. Para fines del período colonial, Buenos Aires contaba por lo menos con siete cofradías de ánimas, con sede en cada una de las parroquias de la ciudad, incluida la catedral, además de una en el hospital de los betlemitas. Dado que estaba prohibido que hubiera más de una hermandad con idéntico título dentro de una misma ciudad, los cofrades las constituían bajo otras devociones, a las que se adosaba en segundo lugar la de ánimas. En este contexto, no es casual que cuatro de estas cofradías fundadas en la segunda mitad del siglo XVIII se erigieran bajo la protección de advocaciones marianas (Nuestra Señora de los Dolores, del Socorro, del Carmen y de los Remedios). f. 147.

29 AGN, Sucesiones, 3865, Testamentaria de Baltasar de Arandía,

30 Ídem

31 AGN, 9-31-8-5, exp. 1355, f. 1.
La elección de la Virgen María por parte de los fieles porteños no era un hecho excepcional. Inmaculada Arias de Saavedra y Miguel López-Guadalupe $\operatorname{Muñoz~}(1998,203)$ sostienen que, a fines del siglo XVIII, «las cofradías marianas sobrepasan el 30 por ciento del total» en casi todas las ciudades españolas. Sin embargo, de acuerdo con estos autores, en la península eran mucho menos frecuentes las cofradías de ánimas y las mixtas (consagradas a dos o más devociones). La estrecha vinculación entre el culto mariano y el de las benditas ánimas, tal como se evidencia en Buenos Aires, expresa la confluencia entre este renovado fervor devocional y la expansión de la estructura parroquial de la ciudad a partir de la década de $1770 .{ }^{32} \mathrm{Al}$ momento de elegir la advocación bajo la que se situaría la nueva cofradía, los fieles optaban por aunar el culto mariano al de las benditas ánimas. De esta manera se conciliaba la vieja piedad de cuño barroco con el nuevo rol asignado al clero secular y a la institución parroquial.

Los proyectos ilustrados de reforma tuvieron en Buenos Aires un alcance mucho más limitado que en la península. ${ }^{33}$ La fundación de nuevas hermandades no se detuvo hasta fines del período colonial, llegando a generar conflictos y disputas de gravedad. La cofradía de Dolores, por ejemplo, se quejaba de la merma en la recolección de limosnas, producto de la fundación de otra hermandad de ánimas, establecida en la nueva parroquia de San Nicolás. ${ }^{34}$ En 1791 el obispo Azamor y Ramírez se negó a autorizar el funcionamiento de la cofradía de Nuestra Señora de los Remedios y Ánimas, fundada veinte años antes en la capilla de San Miguel, argumentando que ya había una hermandad de ánimas en ese curato (San Nicolás) y que estas debían estar asentadas «en las Parroquias por ser la Matriz de los fieles». ${ }^{35}$ Asimismo, los feligreses de la parroquia del Socorro parecen haber tenido muy en cuenta este antecedente en su presentación de 1799, ya que se sintieron en la obligación de justificar pormenorizadamente sus pretensiones de fundar una cofradía análoga en ese curato. ${ }^{36}$

La relación entre el culto mariano y el de las benditas ánimas era muy estrecha. Así lo entendían los cofrades de la Hermandad de Dolores, al destacar el papel salvífico de la Virgen María: «desiende aquella Madre de misericordia a sacar con tanto gusto las Almas de los pecadores, y principalmente las de sus devotos, que estan en aquel profundo lago de llamas, como los peses en las Aguas del mar».37 Los hermanos reforzaban esta imagen a partir de diversas citas de autores cristianos, como San Buenaventura, San

32 Sobre la división parroquial de Buenos Aires a fines del período colonial, cfr. Salvia (2003).

33 El programa reformista impulsado durante el reinado de Carlos III al igual que la desamortización de 1798 suscitaron serios problemas para las cofradías españolas. Según López Carvajal (2013), en Nueva España las reformas no se hicieron sentir con la misma fuerza que en la península, pero las cofradías sufrieron un duro golpe con la consolidación de vales reales de 1804, como señala G. Von Wobeser (2006). A diferencia, de lo que ocurría tanto en la península como en Nueva España, en el Río de la Plata el proceso de desamortización tuvo un alcance muy limitado. Sobre esto último, cfr. Levaggi (1986).

34 AGN, Biblioteca Nacional, 395, exp. 6608, f. 173-174.

35 AGN, 9-31-6-2, exp. 858, f. 28. Sobre esta cofradía, cfr. González Fasani (2006, 290-291).

36 AGN, 9-31-8-5, exp. 1355. Sobre esta cofradía, cfr. González (2005, 325-335) y González Fasani (2006, 278-283).

37 AGN, Biblioteca Nacional, 395, exp. 6608, f. 9. 
Bernardino de Siena, o Santa Brígida, a quien la Virgen le había dicho "Yo soy Madre de todos los que se hallaren en el purgatorio, cuyas penas por mis ruegos en todas las horas del día las mitigan ${ }^{38}$

En su escrito de 1799, los cofrades del Socorro establecían la misma relación entre el culto mariano y el de las benditas ánimas. Para los hermanos, la elección de la patrona guardaba una estrecha afinidad con los objetivos de la cofradía:

A la verdad que si vuscamos en nuestra eleccion razones de congruencia en ninguna otra las encontrariamos mas adequadas por la proporcion de la Madre de Misericordia bajo el titulo de Nuestra Señora del Socorro con los fines que nos estimulan al alivio de las Benditas Animas, y en nuestro propio aprovechamiento en el socorro de todas nuestras necesidades y miserias. ${ }^{39}$

Al igual que lo haría Serra y Valls unos años más tarde, los fieles del Socorro asociaban a María con la misericordia y el alivio de las benditas ánimas. Basándose en San Bernardino, los cofrades señalaban:

El poder de esta Señora trasciende hasta los abismos. Entra, dice el santo, con autoridad de Reyna en aquellos obscuros senos, y desata las prisiones de los reos no pasandose hora del dia sin que se mitigue el rigor de sus penas por su intercesion, cumpliendo en esto con el oficio de Madre de las Almas todas que estàn en el Purgatorio. ${ }^{40}$

«Madre de las Almas» y "reyna en aquellos obscuros senos», María tenía la potestad de aliviar las penas y sacar a los fieles del purgatorio. Como apuntaban los cofrades de la Hermandad de Dolores, la Virgen era "Patrona, Protectora, Abogada, no solo para vida y muerte, sino tambien para despues de la muerte ${ }^{41}{ }^{4}$ La imaginería colonial reflejaba y reforzaba esta potencia salvífica atribuida a la Virgen. El lienzo corredizo o velo del altar de la cofradía de Dolores (Fig. 4) se componía de una típica representación de esta advocación mariana, rodeada de nubes y querubines. Debajo de esta, las figuras desnudas en actitud de súplica representaban a las ánimas purgantes que dirigían su mirada a la Madre Dolorosa.

Nuestra Señora del Carmen era otra advocación estrechamente asociada a las ánimas del purgatorio. Según Manuel Hernández $(1992,167)$, «en el siglo XVIII, la penetración del culto mariano dentro del conjunto de preocupaciones de la vida postmortem [...] recibe un espaldarazo definitivo con la extensión del culto a una Virgen que, progresivamente, se irá convirtiendo en personaje dominante de la escena ultraterrena: la Virgen del Carmen». En la pintura colonial se la solía representar junto a los fieles purgantes y como liberadora de las almas retenidas en "aquellos obscuros senos». Este es el caso del lienzo costeado por José Ventura de Laprida y su esposa María Ignacia Sánchez de Loria, que se conserva actualmente en el Complejo Museográfico Udaondo de Luján (Fig. 5). Representaciones similares, aunque quizás de factura más

\footnotetext{
38 Citado en González (2005, 255).

39 AGN, 9-31-8-5, exp. 1355, f. 3.

40 Ídem.

41 AGN, Biblioteca Nacional, 395, exp. 6608, f. 12.
}

\section{FIGURA 4}

Virgen Dolorosa, anónimo (Madrid), óleo sobre tela pegada sobre madera terciada, 1794. Buenos Aires, Catedral Metropolitana

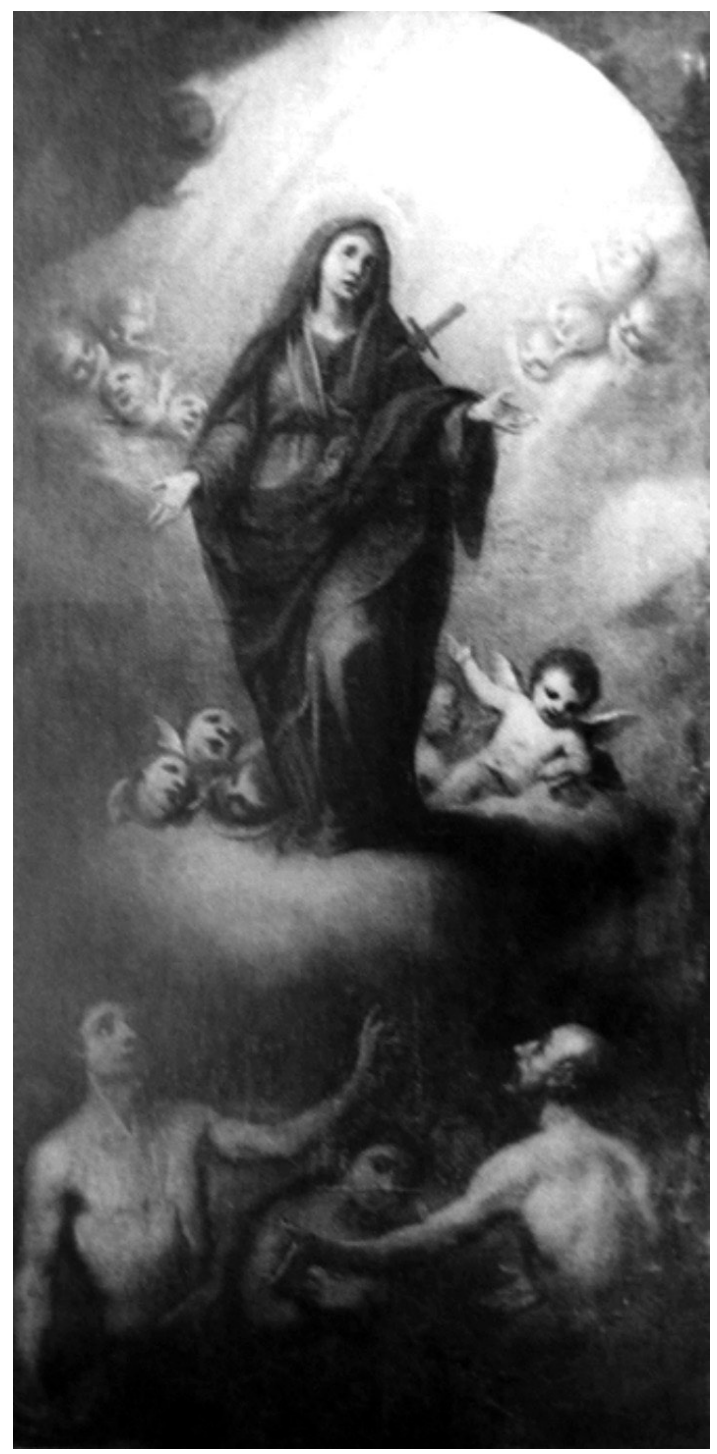

Fuente: Reproducida en ANBA $(1998,64)$

simple, eran usuales dentro de la imaginería de uso privado, como atestigua la testamentaria del comerciante Eugenio Lerdo de Tejada, quien poseía entre sus cuadros piadosos una "Virgen del Carmen con las ánimas». ${ }^{42}$ Este poder salvífico estaba estrechamente asociado a las propiedades del escapulario, que protegía de la muerte y aliviaba las penas del purgatorio. Como señala Patricia Fogelman $(2014,227)$, «en el año 1322, el Papa Juan XXII anunció que había visto una aparición de la Virgen que le dijo que "consolaría en el purgatorio a los cofrades del Santo escapulario, sacándolos de este lugar el primer sábado después de su muerte"». De esta forma, la promesa mariana apaciguaba las angustias y ansiedades de los fieles, garantizando una pronta liberación de las penas del purgatorio.

\footnotetext{
42 AGN, Sucesiones, 6727, Testamentaria de Eugenio Lerdo de
} Tejada. 


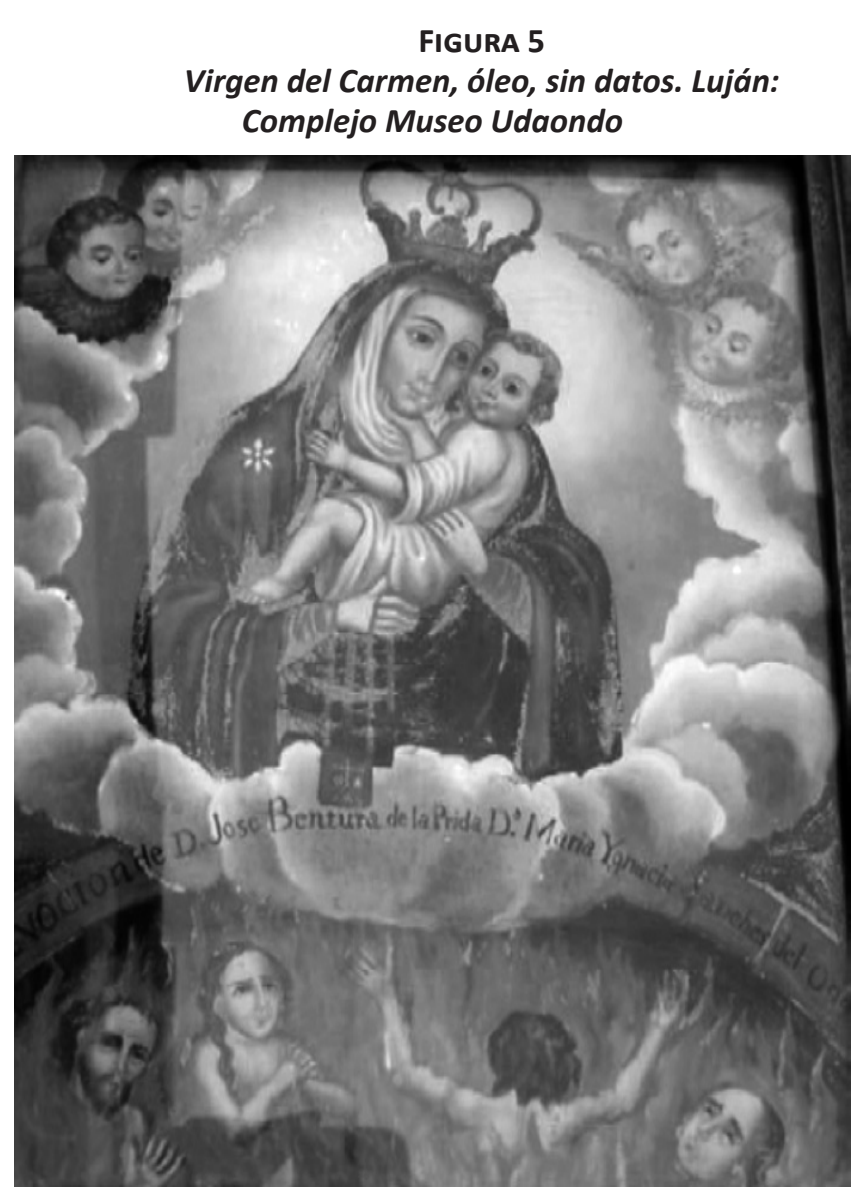

Fuente: Reproducido en Fogelman $(2014,227){ }^{43}$

Sin embargo, la confianza ciega en la potencia salvífica de la Virgen, a la que «su Hijo nada podía negarle», podía resultar contraria a la ortodoxia de la Iglesia. La misericordia mariana no podía comprometer la rectitud de la justicia divina ni ir en contra de los designios de Dios. La Iglesia procuraba establecer un equilibrio entre la incredulidad de los "falsos reformadores» y la confianza desmedida y en ocasiones ingenua del feligrés barroco. Un sermón pronunciado en Buenos Aires hacia fines del período colonial advertía sobre los excesos a los que podía llevar la devoción mariana:

Si queremos imaginar que con la proteccion de Maria nada nos ha de costar la salvacion que con haber cumplido algunos exercisios de la falsa piedad respecto de Maria podemos satisfacer a Dios de lo demas; y que por llevar un havito o escapulario de María estamos libres de los peligros del mundo, de los temores de la muerte, de todas las iras del Cielo, y que con eso no tenemos que temer [...] si asi lo entendemos no es del modo que lo entiende Dios. ${ }^{44}$

La piedad barroca, en sus excesos y exterioridades, solía desbordar los límites de la ortodoxia, al atribuirle a la Virgen funciones y prerrogativas exclusivas de Dios. Como señala Patricia Fogelman (2003, 421), "pese a que la Madre de Cristo no debería ser considerada omnipotente, en la práctica los comunes excesos de los devotos llegan a sobrepasar

43 Agradezco a la Dra. Patricia Fogelman, que gentilmente me permitió reproducir la imagen.

${ }^{44}$ AGN, Biblioteca Nacional, 353, exp. 6129, Sermón de Nuestra Señora de las Nieves. los límites atribuidos a la Virgen». Incluso aquellos fieles que reconocían haber llevado una mala vida, como el vizcaíno José Treviño, acusado en 1803 de impiedad y blasfemia ante el comisario de la Inquisición de Buenos Aires, esperaban salvarse gracias a la intervención de la Madre de Dios. A pesar de haber afirmado que la fornicación no era pecado y que no creía en los santos, el mismo Treviño decía que «tenia mucha confianza en la misericordiosa intercesion de Nuestra Señora del Carmen $"{ }^{45}$ Como demuestran estos testimonios, dentro del imaginario barroco la protección de María era considerada un recurso casi infalible a la hora de asegurarse la salvación.

\section{EL AMOR, LA FAMILIA Y LA «PATRIA»}

Para los hombres del siglo XVIII, el testamento era en sí mismo un instrumento salvífico. Además de sus implicancias económicas y profanas, este documento servía al fiel para realizar el "descargo de su conciencia» y reconocer las faltas y "deudas» contraídas en vida. Los listados de acreedores, la manumisión de esclavos y el reconocimiento de hijos naturales eran muy frecuentes en los testamentos coloniales. Pero también las deudas espirituales debían ser saldadas ante la inminencia de la muerte. Así lo entendieron, por ejemplo, los albaceas de Lázaro Álvarez, capitán de milicias de naturales, al pagar dos pesos de limosna por las misas de que era «deudor dicho difunto a la virgen de Luján». ${ }^{46}$ Más explícita fue Juana Almirón, vecina de los Arrecifes, en su poder para testar de 1793:

Item mando que en el dicho conbento [del Rincón de San Pedro] se me mande decir una misa rezada a nuestra Madre y Señora del Socorro y que mi nieta Juana Celidonia le haga en mi nombre una visita por ser promesa que le tengo hecho. Item mando que a nuestra Señora de Lujan le manden decir tres misas por ser promesa que tambien le tengo hecho. ${ }^{47}$

La devoción a la Virgen de Luján, originada en 1630, se transluce con particular intensidad en muchos testamentos. ${ }^{48}$ Las advocaciones tradicionales españolas y de raigambre regional también ocupaban un papel destacado en la devoción de los fieles porteños. En su testamento de 1765, María Petrona Gutiérrez pidió que se dijeran misas a la Virgen de los Remedios y a Nuestra Señora de los Desamparados, advocación tradicional valenciana..$^{49}$ Por su parte, Vicente de Azcuénaga, natural de Vizcaya y uno de los comerciantes más ricos de Buenos Aires, instituyó en su testamento de 1787 una capellanía con un principal de 2000 pesos para que se dijera misa «todos los días de fiesta» a las once y media de la mañana en el altar de Nuestra Señora de Begoña, en la Capilla de San Roque. No es casual que la elección de Azcuénaga haya recaído en esta advocación mariana, declarada en 1738 patrona de Vizcaya, tierra natal

45 Archivo Histórico Nacional (AHN), Madrid, Inquisición 3730, exp. 92, f. 2. Disponible en: <http://pares.mcu.es/ParesBusquedas20/ catalogo/description/3670002>

46 AGN, Sucesiones, 3866, Testamentaria de Lázaro Álvarez, f. 24.

47 AGN, Sucesiones, 3866, Testamentaria de Juana Almirón, f. 1.

48 Sobre la devoción a la Virgen de Luján en los siglos XVII y XVIII, cfr. Fogelman (2003, 71-140).

${ }^{49}$ AGN, Sucesiones, 7151, Testamentaria de María Petrona Gutiérrez. 
del testador. La Virgen, en sus múltiples advocaciones, podía simbolizar también el amor por la «patria», rememorada con nostalgia en los últimos instantes de la vida. ${ }^{50}$

En otros casos, la devoción a una imagen o advocación en particular poseía un trasfondo familiar y revestía una carga afectiva específica. Al regresar de un viaje a España, en 1734, Ignacio Bustillos Cevallos y su esposa, Ana Rabanal, traen consigo una imagen de Nuestra Señora de Belén y realizan una donación a la Compañía de Jesús para edificar una iglesia y casa de ejercicios bajo esta advocación, en el Alto de San Pedro. ${ }^{51}$ Al morir, ambos son enterrados en aquel templo. Su yerno, el riojano Eugenio Lerdo de Tejada, se hizo eco de este fervor mariano en su testamento de 1787 :

Item por quanto mi difunta muger Doña Maria Josefa Cevallos a exemplo, e imitacion de sus Padres fue especial devota a Nuestra Señora de Bethlem, y esta misma Devocion de mucho tiempo aca tiene hechadas profundas rayces en mi corazon: Quiero ordeno, y mando que todos los años perpetuamente, en el dia ocho de septiembre [...] se celebre fiesta solemne con Misa Cantada y Sermon en reverencia del misterio del Nacimiento temporal del Divino verbo en el Portal de Bethlem. ${ }^{52}$

Viudo y sin hijos, Lerdo de Tejada destacaba las «profundas raíces» que esta devoción había echado en su corazón y la asociaba con el recuerdo de su difunta esposa y familia. Una sutil afinidad unía a esta advocación dilecta con el amor y la «tierna memoria» que él sentía por su esposa. Antes de fallecer, Lerdo había dejado pactado un contrato con el tallista Tomás Saravia para la construcción de un retablo dedicado a Nuestra Señora de Belén, en la iglesia del convento de las capuchinas. Para esto había legado además unas cornucopias y espejos de su propiedad. Entre sus últimas disposiciones, también había ordenado la fundación de varias capellanías, una de ellas a beneficio de su alma, la de su esposa, sus suegros y una sobrina, que no casualmente se llamaba también María Belén. ${ }^{53}$ Disposiciones como las de Lerdo de Tejada ilustran los lazos recíprocos que conectaban a ambos mundos, el de los vivos y el de los muertos, la Iglesia militante y la purgante. La devoción mariana podía servir también como un vehículo ideal para expresar esta solidaridad entre vivientes y difuntos. Al mismo tiempo, la figura maternal de María permitía canalizar una forma de piedad más bien doméstica, privada y personal.

El deseo por mantener la devoción más allá de la muerte se expresa en las disposiciones de otros testadores porteños del período tardocolonial. Por ejemplo, el portugués Antonio de Castro había dispuesto en 1776 que se le dejara a la hermandad del Rosario de la Merced «un vestido, con advertencia que ha de ser para la Virgen, que se halla en el Nicho de su Capilla, y cofradía»..$^{54}$ Otro testador, Antonio

50 Martínez de Sánchez $(1996,133)$ constata comportamientos similares entre los testadores cordobeses del siglo XVIII.

51 Sobre la iglesia de Nuestra Señora de Belén, luego parroquia de San Telmo, cfr. Luqui Lagleyze (1981, 115-120).

52 AGN, Sucesiones, 6727, Testamentaria de Eugenio Lerdo de Tejada.

53 La relación entre Lerdo y su familia política parece haber sido particularmente estrecha, ya que compartía la misma casa (y varios negocios) con su concuñado, el también riojano Bernardo Sancho de Larrea, y con un sobrino de éste, Ilamado Miguel. Cfr. Socolow (1978, 75 y 181$)$.

54 AGN, Protocolos notariales, Registro 1, 1776, f. 68.
Vélez, dispuso en 1790 que se costearan los gastos de la fiesta de los padres de María, San Joaquín y Santa Ana, y liberó a sus esclavos con la "pensión» de que sirvieran y tocaran música «todos los años de su vida» en dicha celebración. ${ }^{55}$ Legar una imagen piadosa, muchas veces con la obligación de mantener su aseo y culto, también constituía una práctica frecuente. Como señala Martínez de Sánchez $(1996,133)$, esta práctica respondía al «doble fin de manifestar un sentimiento personal y ayudar a que no se perdiera esa costumbre entre sus devotos». Bartolomé Lastra, vecino de Buenos Aires y natural de Sanlúcar de Barrameda, era terciario dominico y particularmente devoto de Nuestra Señora del Rosario. Entre sus bienes se contaba una imagen de esta advocación, colocada en un nicho de jacarandá con vidriera. También era dueño de una lancha, a la que había bautizado Nuestra Señora del Rosario y Ánimas. En su testamento de 1794, Lastra dispone que el sobrante de su quinto se le dé a

\begin{abstract}
qualquiera de mis hijos que fuere mas deboto de nuestra Señora del Rosario, lo tenga a réditos y con el producto se le diga un novenario de misas todos los años a la efigie de esta advocacion que debera tener en su poder a efecto de cuidar de que se digan las referidas misas aplicandonse estas por mi intención. ${ }^{56}$
\end{abstract}

Otra devoción particularmente popular era la Inmaculada Concepción, advocación estrechamente vinculada a la monarquía española y a ciertas órdenes religiosas, como jesuitas y franciscanos. Aunque esta cuestión dividía aguas entre los propios católicos, la Inmaculada ganó una enorme popularidad durante la Contrarreforma y fue una de las repuestas más audaces de la Iglesia ante los cuestionamientos protestantes. Según Marina Warner $(2013,253)$, ésta era «una de las ideas católicas que más disgustaba a los reformadores, y por lo tanto expresaba el desafío y la audacia de la Iglesia romana». Este debate tenía enormes consecuencias antropológicas, ya que introducía un elemento clave (la ausencia del pecado original), que distinguía a la Madre de Dios del resto de la humanidad. Al mismo tiempo, esta cuestión se relacionaba con otro tema polémico, la muerte o asunción de la propia Virgen María. Como señala Patricia Fogelman (2003, 34), «es importante tomar en cuenta que el proceso de unificación de opiniones respecto de la Inmaculada Concepción de la Madre de Jesús se constituye en un período marcado por la contraposición a la Revolución francesa y las ideas de la llustración». Las posiciones concepcionistas contaron con el apoyo decidido de los monarcas españoles y se constituyeron en un puesto de avanzada en la lucha contra la «impiedad y libertinaje» del siglo de las Luces.

Según Estela Barbero (1994, 328), la Inmaculada Concepción era la advocación mariana más popular entre los porteños. A ella estaba dedicada una cofradía específica, fundada en el convento de San Francisco a principios del siglo XVII y restablecida, luego de un cierto período de inactividad, en $1804 .{ }^{57}$ Incluso la imagen de Nuestra Señora

\footnotetext{
55 AGN, Protocolos notariales, Registro 1, 1790, f. 197.

56 AGN, Sucesiones, 6727, Testamentaria de Bartolomé de Lastra, f. 9 .

57 Cfr. AGN, 9-31-8-5, exp. 1368. Para un panorama general de esta cofradía, cfr. González (2005, 98-107).
} 
de Luján, tan venerada en el Buenos Aires colonial, era una representación de esta tradicional advocación mariana. A la «Limpia Concepción» estaba consagrada además una iglesia en el Alto de San Pedro, convertida en vice-parroquia en 1748 y erigida en curato en el año $1769 .{ }^{58}$ Esta devoción también estaba presente en las disposiciones testamentarias de la época. Algunos encabezados y profesiones de fe aludían expresamente a este misterio, a pesar de no ser aún reconocido como un dogma de la Iglesia. Por ejemplo, Juana Rosa Flecha, vecina de la Cañada de Escobar, comenzaba su testamento de 1798 de la siguiente manera: «En el nombre de Dios todopoderoso, y de la Birgen Santisima, su madre, y señora nuestra, Consevida sin mancha, ni sombra, de la culpa original, en el primer ynstante de su ser purísimo y natural Amen». ${ }^{59}$ Incluso los novicios dominicos, orden tradicionalmente refractaria al concepcionismo, comenzaban sus testamentos invocando a María como «Madre de Gracia concevida en ella desde el primer Instante de su animación Purísima por no haberle comprehendido ni aun Sombra de la original Culpa». ${ }^{60}$

Algunos testadores elegían su altar para que se dijeran sufragios o realizaban legados y donaciones. Por ejemplo, en 1791 el gaditano José Pío Goity dispuso se mandaran decir seis misas a la imagen de la Concepción que se encontraba en la portería del convento de San Francisco. ${ }^{61}$ Otros se servían de la fundación de capellanías, como el vizcaíno Antonio Larrazábal, que dispuso en su testamento de 1757 que se costeara con sus réditos "la fiesta de la Purísima Concepción" y las misas y aseo del altar de San José, en la Catedral. ${ }^{62}$

En algunos casos la devoción se constituía en una verdadera tradición familiar. En su testamento de 1772, Antonia Santuchos pedía ser sepultada en la iglesia de la Concepción, de la que era particularmente devota, al igual que lo había sido su difunta madre:

Mi cuerpo sea sepultado en la Iglesia de la Pura y Limpia concepcion, en donde tengo sepultura yo la otorgante, y mi familia por contrato verbal que tenemos Celebrado con Don Mathias Flores Maiordomo de aquella fabrica por la devocion que yo, y mi madre hemos tenido de concurrir en obsequio de la Pura y Limpia concepcion, con lo que nos ha sido posible para su anual fiesta, como se ha verificado todos los años componiéndose la Imagen que tengo en Casa, para que sirva en la Prosecion. ${ }^{63}$

En su casa, Antonia poseía la imagen dentro de un nicho colocado sobre una mesa cuadrada, alrededor de la cual se encontraban colgadas "ocho laminas como de tercia con sus marcos dorados, [...] pertenecientes al adorno de la Pura y Limpia». ${ }^{64}$ Todos los años, la imagen era retirada de esta suerte de "altar doméstico» para ser llevada en andas hasta

\footnotetext{
58 Sobre la iglesia de La Concepción, cfr. Luqui Lagleyze (1981, 107-110).

59 AGN, Sucesiones, 5873, Testamentaria de Juana Rosa Flecha.

60 AGN, Protocolos notariales, Registro 5, 1782, f. 63.

61 AGN, Protocolos notariales, Registro 1, 1791, f. 368.

62 AGN, Sucesiones, 5873, Manuel Antonio Warnes contra los bienes..., f. 4.

63 AGN, Sucesiones, 8418, Testamentaria de Antonia Santuchos, f. 6

64 Ibídem, f. 7.
}

la iglesia de la Concepción. Antonia procuraba perpetuar esta devoción entre sus hijas y confiaba en que la intercesión de la Inmaculada le permitiera alcanzar la «patria celestial»:

Asi como mi difunta Madre me dexo la devocion de cuidar el aseo de la Pura y Limpia concepcion que sale en andas desde mi casa [...], queriendo se perpetue en lo posible esta devocion en mi familia, es mi voluntad que mi Marido quede hecho cargo de esta funcion, y por su falta la que buenamente quisiese de mis hijas suplicandoles a estas procuren esmerarse en el aseo de esta Divina Señora pues mediante su intersecion me prometo conseguir la Selestial Patria. ${ }^{65}$

La devoción mariana, las ansias de salvación y los sentimientos de familia se entrelazaban en el momento de la muerte. Para fieles como Antonia Santuchos, la intercesión de la Virgen no constituía una simple formalidad o una figura retórica, sino una esperanza concreta de salvación. La vida cotidiana se nutría de prácticas devocionales y formas específicas de religiosidad que excedían ampliamente el marco de las fórmulas notariales y de las grandes celebraciones públicas. Una piedad más interior y personal comenzaba a perfilarse en el siglo de las Luces. Como señala Franco Rubio $(2015,25)$, «había formas individualizadas de vivir la religión a través de la piedad personal». Esta religiosidad privada se expresaba en «los interiores domésticos donde pilas de agua bendita, muebles como los escaparates, cuadros, estampas y grabados permitían tener siempre presente imágenes religiosas a las que invocar en cualquier momento» (ibíd.). La figura de María concitaba un culto privado e íntimo que permitía reforzar los vínculos familiares y de solidaridad entre vivos y difuntos, al mismo tiempo que la convertía en la compañía más preciada de los moribundos.

\section{CONSIDERACIONES FINALES}

Los estudios cuantitativos de testamentos han constatado la presencia persistente de la invocación mariana en las últimas voluntades. Sin embargo, despojados de todo contexto, estos datos poco nos dicen de las intenciones, temores y preocupaciones de aquellos moribundos. Como señala José Pedro Barrán, «los documentos podrán contarse, pero siempre deben leerse» $(1998,27)$. En este trabajo hemos procurado analizar algunos de los mecanismos mediante los cuales se expresaba esta estrecha relación entre muerte y culto mariano, resituando esta devoción dentro del marco de la piedad barroca que imperaba en Buenos Aires a fines del período colonial. A su vez, estas indagaciones nos permiten profundizar en las intenciones, inquietudes, temores y angustias del fiel católico que invocaba el nombre de María en los últimos instantes de su vida. Tanto el temor a la muerte como al sufrimiento y la condenación eterna acicateaban la piedad del feligrés barroco.

Una gran variedad de prácticas devocionales da cuenta de la preeminencia del culto mariano dentro de la piedad barroca tardocolonial, así como del papel crucial que ella desempeñaba dentro de esta particular economía de la salvación. Las promesas y exvotos, las plegarias, los sufragios en sus múltiples altares, los legados para costear sus fiestas, al igual que la proliferación de cofradías y hermandades

\footnotetext{
65 Ibídem, ff. 7-8.
} 
bajo su protección, dan cuenta de la potencia salvífica popularmente atribuida a la Virgen María. Este fervor devocional, en ocasiones rayano en la heterodoxia, expresaba una forma de piedad que desbordaba los estrechos límites de las fórmulas notariales. A diferencia de lo que ocurría en España, donde las reformas se hacían sentir con más fuerza, la consolidación del culto mariano en el Buenos Aires tardocolonial expresaba la persistencia de la vieja religiosidad barroca, pero también la articulación de nuevas formas de piedad, más intimas y personales. En un contexto de fuerte crecimiento económico y demográfico de la ciudad, la expansión de las actividad cofradiera y de otras formas públicas de devoción confluía con el desarrollo de nuevas modalidades de religiosidad, más ligadas al espacio doméstico y familiar. Ambas apelaban al culto mariano como objeto de devoción y esperanza de salvación.

El carácter humano de María, su condición de madre y su profundo conocimiento de la muerte, tanto la propia como la ajena, reforzaban su imagen de intercesora y abogada misericordiosa. A ella se recurría tanto para preservar la vida como para asegurar la «buena muerte» y la salvación del alma. Además, el culto mariano constituía un medio eficaz para expresar los últimos deseos e inquietudes del testador. El amor conyugal, el sentimiento de familia y la añoranza por la «patria» perdida podían ser codificados y sublimados en el culto mariano. Estas prácticas devocionales implicaban una forma muy particular de intimidad con lo divino. La Virgen, en sus múltiples formatos y ropajes, ofrecía no solo una esperanza de salvación sino también una posibilidad de identificación y de consuelo en ese último y «tremendo lance».

\section{FUENTES}

Academia Nacional de Bellas Artes. 1998-2010. Inventario de Bienes muebles. Ciudad de Buenos Aires, t. I-IV. Buenos Aires: Academia Nacional de Bellas Artes.

Astete, Gaspar. 1787. Catecismo de la doctrina christiana... Valladolid: Imprenta de Don Manuel Santos Matute.

Caton Christiano, o explicacion de la doctrina christiana... 1795. Buenos Aires: Real Imprenta de los Niños Expósitos.

Reymundínez, Lorenzo. 1785. Congregante y siervo perfecto de la SSma. Virgen de los Dolores. Barcelona: Francisco Suria y Burgada.

Ribera, Adolfo Luis y Héctor Schenone. 1948. El arte de la imaginería en el Río de la Plata. Buenos Aires: Universidad de Buenos Aires Instituto de Arte Americano e Investigaciones Estéticas.

San Alberto, José Antonio. 1789. Voces del Pastor en el Retiro. Dispertador, y exercicios espirituales, para vivir y morir bien... Buenos Aires: Real Imprenta de los Niños Expósitos.

Serra y Valls, José. 2000. Colección de versos: Buenos Aires, 1807-1810. Buenos Aires: Academia Nacional de la Historia.

\section{BiBLIOgRAFÍA}

Alemán Illán, Anastasio. 2001. Actitudes colectivas ante la muerte en Murcia durante el siglo XVIII. Tesis doctoral inédita. Universidad de Murcia.

Arias de Saavedra Alías, Inmaculada y Miguel López-Guadalupe Muñoz. 1998. "Cofradías y ciudad en la España del siglo XVIII». Studia historica. Historia moderna. 19: 197-228.

Arias de Saavedra Alías, Inmaculada y Miguel López-Guadalupe Muñoz. 2017. «Las cofradías españolas en la Edad Moderna desde una óptica social. Tres décadas de avance historiográfico». Cuadernos de estudios del siglo XVIII 27: 11-50.

Ariès, Philippe. 1984. El hombre ante la muerte. Madrid: Taurus.

Barbero, Estela. 1994. «Imaginería». En Lo suntuario en la vida cotidiana del Buenos Aires virreinal: De lo material a lo espiritual, Nelly Raquel Porro Girardi y Estela Barbero. Buenos Aires: PHRISCO - CONICET.

Barral, María Elena. 1998. «Limosneros de la Virgen, cuestores y cuestaciones: La recolección de la limosna en la campaña rioplatense, siglo XVIII y principios del XIX». Boletín del Instituto de Historia Argentina y Americana «Dr. Emilio Ravignani» 18: 7-33.

Barral, María Elena. 2007. De sotanas por la Pampa. Religión y sociedad en el Buenos Aires rural tardocolonial. Buenos Aires: Prometeo.

Barrán, José Pedro. 1998. La espiritualización de la riqueza: catolicismo y economía en Uruguay (1730-1900). Montevideo: Ediciones de la Banda Oriental.

Di Stefano, Roberto. 2002. «Orígenes del movimiento asociativo: de las cofradías coloniales al auge mutualista, 1776-1860». En De las cofradías a las organizaciones de la sociedad civil: historia de la iniciativa asociativa en Argentina, 1776-1990, 23-97. Buenos Aires: Edilab.

Di Stefano, Roberto y Loris Zanatta. 2000. Historia de la Iglesia argentina. Desde la Conquista hasta fines del siglo XX. Buenos Aires: Grijalbo Mondadori.

Fogelman, Patricia. 2000. «Una cofradía mariana urbana y otra rural en Buenos Aires a fines del período colonial». Andes 11.

Fogelman, Patricia. 2003. La Omnipotencia Suplicante. El culto mariano en la ciudad de Buenos Aires y la campaña en los siglos XVII y XVIII. Tesis doctoral inédita. Universidad de Buenos Aires.

Fogelman, Patricia. 2010. "Las representaciones de la Virgen María en el cielo. Una aproximación al imaginario cristiano americano colonial». En Entre cielos e infiernos. Memoria del V Encuentro Internacional sobre Barroco, 167-176. Pamplona: Fundación Visión Cultural - Universidad de Navarra.

Fogelman, Patricia. 2014. «El cuerpo de la Virgen: Discursos teológicos y representaciones históricas del cuerpo y la muerte de María». Revista Cultura y Religión VIII, 2: 197-231.

Franco Rubio, Gloria. 2015. «Fragmentos de cotidianeidad. Historiar lo cotidiano». Cuadernos de Historia Moderna 14: 11-32. https://doi. org/10.5209/rev_CHMO.2015.51177

García Fernández, Máximo. 2003. «Vida y muerte en Valladolid. Un estudio de religiosidad popular y mentalidad colectiva: los testamentos». En La Religiosidad Popular II. Vida y Muerte: la imaginación religiosa, coord. Carlos Álvarez Santaló, María Jesús Buxó Rey y Salvador Rodríguez Becerra, 224-243. Barcelona: Anthropos.

González, Ricardo. 2005. Arte y cofradías: Los signos de la unión. Tesis doctoral inédita. Universidad de Buenos Aires.

González Fasani, Ana Mónica. 2006. «El espíritu cofradiero en el Buenos Aires colonial (siglos XVII-XVIII)». En De prácticas, comportamientos y formas de representación social en Buenos Aires (s. XVII-XIX), coord. Hilda Raquel Zapico, 261-295. Bahía Blanca: Universidad Nacional del Sur.

Gómez Navarro, Soledad. 2010. «Historiografía e historia de las actitudes ante la muerte: la España del antiguo régimen vista desde la provincia de Córdoba». Nuevo Mundo Mundos Nuevos. https:// doi.org/10.4000/nuevomundo.60167

Hernández, Manuel. 1990. La muerte en Canarias en el siglo XVIII (Un estudio de historia de las mentalidades). Santa Cruz de Tenerife: Centro de la Cultura Popular Canaria.

Jijena, Lucrecia. 2006. La Tercera Orden de Santo Domingo: presencia en Buenos Aires durante el siglo XVIII. San Miguel de Tucumán: Universidad del Norte Santo Tomás de Aquino.

Levaggi, Abelardo. 1986. "La desamortización eclesiástica en el Virreinato del Río de La Plata». Revista de Historia de América 102: 7-89.

López Carvajal, David. 2013. "La reforma de las cofradías en el siglo XVIII: Nueva España y Sevilla en comparación. Estudios de historia novohispana». Estudios de historia novohispana 48: 3-33.

López Carvajal, David. 2015. «La reforma de las cofradías novohispanas en perspectiva comparada: procedimientos, definiciones 
y alcances, 1750-1820». En Reformas y resistencias en la Iglesia novohispana, coord. Pilar Martínez López-Cano y Francisco Cervantes Bello, 325-350. México: Universidad Nacional Autónoma de México.

Luqui Lagleyze, Julio Ángel. 1981. Las iglesias de la ciudad de la Trinidad y Puerto de Santa María de los Buenos Aires: 1536-1810. Buenos Aires: Municipalidad de la Ciudad de Buenos Aires.

Martínez de Sánchez, Ana María. 1996. Vida y «buena muerte» en Córdoba durante la segunda mitad del siglo XVIII. Córdoba: Centro de Estudios Históricos.

Martínez Gil, Fernando. 2000. Muerte y sociedad en la España de los Austrias. Cuenca: Ediciones de la Universidad de Castilla-La Mancha.

Minois, Georges. 2005. Historia de los infiernos. Barcelona: Paidós.

Pantoja Barco, Rosita. 2008. Afrodita barroca: fragmentos para el estudio de una sensibilidad de la cultura. Popayán, siglos XVII y XVIII. Quito: Abya-Yala.

Peire, Jaime. 2000. El taller de los espejos: Iglesia e Imaginario, 17671815. Buenos Aires: Claridad.

Rípodas Ardanaz, Daisy, dir. 1996. Imaginería y piedad privada en el interior del virreinato rioplatense. Buenos Aires: PHRISCO-CONICET.
Salvia, Ernesto R. 2003. La creación de parroquias en la iglesia particular de Buenos Aires. 1ra parte. Desde la Colonia hasta 1923. Buenos Aires. Disponible en: http://www.historiaparroquias.com. ar/document/creacion_parroquias_p1.pdf

Sánchez Herrero, José. 2003. La Semana Santa de Sevilla. Madrid: Sílex. Schenone, Héctor. 2008. Iconografía del Arte Colonial: Santa María. Buenos Aires: Universidad Católica Argentina.

Seoane, María Isabel. 2006. Un salvoconducto al cielo. Prácticas testamentarias en el Buenos Aires Indiano. Buenos Aires: Dunken Instituto de Investigaciones de Historia del Derecho.

Socolow, Susan. 1978. The Merchants of Buenos Aires 1778-1810. Family and commerce. Cambridge: Cambridge University Press.

Vovelle, Michel. 1973. Piété baroque et déchristianisation en Provence au XVIIIle siècle. Les attitudes devant la mort d'après les clauses de testaments. Paris: Seuil.

Warner, Marina. 2013. Alone of all her sex. The myth and cult of the Virgin Mary. Oxford: Oxford University Press.

Wobeser, Gisela von. 2006. "La Consolidación de Vales Reales como factor determinante de la lucha de independencia en México, 1804-1808». Historia Mexicana, El Colegio de México 56 (2): 373-425. 